\author{
Євтушевська 0.0. \\ кандидат економічних наук, доцент \\ E-mail: olga163alex@gmail.com \\ Кустурова С.П. \\ магістрант \\ кафедра обліку та аудиту \\ Одеська національна академія харчових технологій \\ вул. Канатна, 112, м. Одеса, Україна, 65039 \\ E-mail: kusturova.sveta@yandex.ru
}

\title{
ПОРІВНЯЛЬНА ОЦІНКА ДЕБІТОРСЬКОЇ ТА КРЕДИТОРСЬКОЇ ЗАБОРГОВАНОСТІ ПІДПРИЕМСТВ
}

\begin{abstract}
У статті досліджено сутність, мету та порядок формування аналізу дебіторської і кредиторської заборгованостей. Встановлено, що дуже велике значення для підприємств мають аналіз і управління дебіторською і кредиторською заборгованістю, що функціонують в умовах ринку. Визначено, що головним завданням управління рухом дебіторської заборгованості $є$ встановлення з покупцями таких договірних відносин, які забезпечують своєчасне і достатнє надходження коштів для здійснення платежів кредиторам. Здійснено порівняльний аналіз дебіторської та кредиторської заборгованостей на підприємствах. Проведені дослідження показали, що упродовж останніх років на кожному підприємстві переважає кредиторська заборгованість, і свідчить про те, що підприємства в майбутньому не зможуть погасити свою кредиторську заборгованість за рахунок дебіторської. Запропоновано вживання заходів щодо управління дебіторською та кредиторською заборгованістю.
\end{abstract}

Ключові слова: дебіторська заборгованість, кредиторська заборгованість, порівняння, аналіз, оцінка.

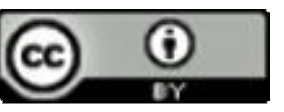

This work is licensed under a Creative Commons Attribution 4.0 International License http://creativecommons.org/licenses/by/4.0/

Постановка проблеми та її зв'язок з важливими науковими та практичними завданнями. Природними складовими бухгалтерського балансу підприємства є дебіторська та кредиторська заборгованість. Вони виникають у результаті розбіжності дати появи зобов'язань 3 датою платежів по них. Впливають на фінансовий стан підприємства як розміри балансових залишків дебіторської та кредиторської заборгованості, так й період оборотності кожної 3 них. Однак балансові залишки дебіторської і кредиторської заборгованості можуть служити лише відправною точкою для дослідження питання про вплив розрахунків 3 дебіторами та кредиторами на фінансовий стан. Якщо дебіторська заборгованість більше кредиторської, це $\epsilon$ можливим фактором забезпечення високого рівня коефіцієнта загальної ліквідності. Одночасно це також може свідчити про більш швидку оборотність кредиторської заборгованості порівняно $з$ оборотністю дебіторської заборгованості. У такому випадку протягом певного періоду борги дебіторів перетворюються на грошові кошти, через більш тривалі часові інтервали, ніж інтервали, коли підприємству необхідні грошові кошти для своєчасної сплати боргів кредиторам. Відповідно виникає нестача грошових коштів в обороті, що супроводжується необхідністю залучення додаткових джерел фінансування.
Дуже велике значення для підприємств мають аналіз і управління дебіторською і кредиторською заборгованістю, що функціонують в умовах ринку. Досить ефективне й вміле управління цією частиною поточних активів є невід'ємною умовою підтримки необхідного рівня ліквідності і платоспроможності. Як при формуванні іміджу надійного позичальника, так і з погляду забезпечення ефективної поточної діяльності підприємства, необхідно управління дебіторською заборгованістю.

Таким чином, оцінка впливу балансових залишків дебіторської та кредиторської заборгованості на фінансовий стан підприємства здійснюється 3 урахуванням рівня платоспроможності (коефіцієнта загальної ліквідності) і відповідності періодичності перетворення дебіторської заборгованості в грошові кошти та періодичності погашення кредиторської заборгованості. В складі поточних активів дебіторська заборгованість має значну питому вагу і впливає на фінансовий стан підприємства. Дуже важливий стан дебіторської заборгованості підприємства і для зовнішніх користувачів інформації, так як іiі зростання завжди свідчить про фінансову нестабільність та погіршення платоспроможності підприємства, внаслідок недоотримання грошових коштів. Погіршення платоспроможності підприємства ставить значну загрозу, щодо банкрутства підприємства, чи у кращому 
разі, погіршення результатів діяльності (гальмування чи припинення розвитку).

Аналіз останніх публікацій 3 проблеми. На сьогоднішній день питанню теоретико-методичного забезпечення аналізу дебіторської та кредиторської заборгованостей на підприємстві присвячена значна кількість робіт як іноземних, так і вітчизняних авторів. Зокрема М. Д. Білик та С. В. Дубровська розкривають проблемні питання сутності поняття «дебіторська заборгованість» $[2,5]$; досить значну увагу аналізу дебіторської заборгованості приділяють О. Г. Лищенко і О. Ніколаєнко [10, 11, 13]; проблеми управління дебіторською заборгованістю в умовах фінансової кризи розглядають В. П. Савчук та Т. Момот $[12,14]$. Також необхідно окремо виділити зарубіжних вчених, таких як Д. Стоун, Зві Бо ді, Дж. Ван Хорн, К. Хитчинг, Роберт К. Мертон які також приділяли важливу увагу вирішенню даного питання [15]. Проте не дивлячись на значний інтерес до цього питання, проблема аналізу стану дебіторської та кредиторської заборгованості на підприємствах України на сьогоднішній день не достатньо вивчена.

Формування цілей дослідження. Метою дослідження $\epsilon$ виявлення існуючих проблем, які пов'язані із станом дебіторської та кредиторської заборгованості та обгрунтування напрямів удосконалення аналізу дебіторської заборгованості підприємств.

Виклад основних результатів та їх обгрунтування. Управління дебіторською заборгованістю та зобов'язаннями включає: аналіз дебіторів та кредиторів підприємства; аналіз реальної вартості дебіторської заборгованості та зобов'язань; розробку політики авансових розрахунків 3 клієнтами підприємства, надання комерційних кредитів; контроль за реальним співвідношенням дебіторської та кредиторської заборгованості; оцінку і реалізацію факторингу. Сдиним засобом для погашення всіх видів кредиторської заборгованості $є$ виручка від продажів. Надходження грошових коштів від продажу визначає можливості підприємства щодо погашення боргів кредиторам. Як правило, велика частина дебіторської заборгованості формується як борги покупців. Головним завданням управління рухом дебіторської заборгованості $є$ встановлення з покупцями таких договірних відносин, які забезпечують своєчасне і достатнє надходження коштів для здійснення платежів кредиторам .

Встановлення таких договірних взаємовідносин 3 постачальниками, які ставлять терміни та розміри платежів підприємства останнім у залежність від надходження грошових коштів від покупців - це управління рухом кредиторської заборгованості [3]. Отже, одночасне управлінні рухом як дебіторської, так i кредиторської заборгованості передбачає наявність інформації про реальний стан дебіторської та кредиторської заборгованості та їх оборотності, тобто оцінка руху дебіторської та кредиторської заборгованості в даному періоді. Тому для такої оцінки в якості вихідних даних досліджують прийняті борги, які пов'язані саме до цього періоду.
Основою для оцінки періодичності надходження боргів покупців, достатнього погашення кредиторської заборгованості, а також балансових залишків дебіторської та кредиторської заборгованості на кінець періоду за умови їх оборотності відповідно до договірних умов або встановленим порядком розрахунків - є частина дебіторської та кредиторської заборгованості, що залишилася після цього. Метою аналізу дебіторської і кредиторської заборгованості $€$ виявлення суми виправ даної і невиправданої заборгованості; зміни за аналізований період, реальність сум дебіторської та кредиторської заборгованості, причини і давність утворення дебіторської заборгованості. У зв'язку з цим аналіз дебіторської і кредиторської заборгованості є важливою частиною фінансового аналізу на підприємстві і дозволяє виявляти не лише показники поточної (на даний момент часу) i перспективної платоспроможності підприємства, але i фактори, що впливають на їх динаміку, а також змогу оцінювати кількісні і якісні тенденції зміни фінансового стану підприємства в майбутньому. Перевищення дебіторської заборгованості над кредиторською означає відволікання коштів з господарського обороту і в подальшому може призвести до необхідності залучення дорогих кредитів банку і позик для забезпечення поточної виробничо-господарської діяльності підприємства. Досить значне перевищення кредиторської заборгованості над дебіторською створює загрозу фінансовій стійкості підприємства.

Порівняльна оцінка дебіторської та кредиторської заборгованості ПАТ «Вінницький олійножировий комбінат» представлена в табл. 1 .

Проаналізувавши кредиторську та дебіторську заборгованості ПАТ «Вінницький олійножировий комбінат» за 2013, 2014 та 2015 роки, можна зробити висновок, що за перші два роки заборгованість за товарами, роботами та послугами перевищення йде на кредиторську заборгованість. За 2013 рік становить 25291 тис.грн., за 2014 рік - 13308 тис.грн. У 2015 році перевищує дебіторська заборгованість на 13370 тис.грн. В заборгованості за розрахунками з бюджетом в усіх трьох роках переважає дебіторська заборгованість, а саме у 2013 році у розмірі 28082 тис.грн., у 2014 році на 5119 тис.грн., у 2015 році на 78330 тис.грн. У іншій поточній заборгованості переважає кредиторська заборгованість. В 2013 році становить 280368 тис.грн., у 2014 році - 108769 тис.грн., у 2015 році - 557415 тис.грн.

Порівняльний аналіз дебіторської та кредиторської заборгованостей у ПАТ «Вінницький олійножировий комбінат» за 2013, 2014, 2015 роки показав про загальне перевищення кредиторської заборгованості над дебіторською: у 2013 році на 277577 тис.грн., у 2014 році на 116958 тис.грн., у 2015 році на 465715 тис.грн.

Порівняльна оцінка дебіторської та кредиторської заборгованості ПАТ «Одеський олійножировий комбінат» представлена в табл. 2. 
Таблиця 1

Дебіторська і кредиторська заборгованість ПАТ «Вінницький олійножировий комбінат», тис. грн.*

\begin{tabular}{|c|c|c|c|c|c|c|c|c|c|c|c|c|}
\hline \multirow{3}{*}{ Показники } & \multicolumn{4}{|c|}{2013 рік } & \multicolumn{4}{|c|}{2014 рік } & \multicolumn{4}{|c|}{2015 рік } \\
\hline & \multicolumn{2}{|c|}{ Заборгованість } & \multicolumn{2}{|c|}{$\begin{array}{c}\text { Перевищення } \\
\text { заборговано- } \\
\text { сті } \\
\end{array}$} & \multicolumn{2}{|c|}{ Заборгованість } & \multicolumn{2}{|c|}{\begin{tabular}{|c|} 
Перевищення \\
заборговано- \\
сті \\
\end{tabular}} & \multicolumn{2}{|c|}{ Заборгованість } & \multicolumn{2}{|c|}{\begin{tabular}{|c|} 
Перевищення \\
заборгованос- \\
ті \\
\end{tabular}} \\
\hline & $\begin{array}{l}\text { дебі- } \\
\text { тор- } \\
\text { ська }\end{array}$ & $\begin{array}{l}\text { кре- } \\
\text { ди- } \\
\text { тор- } \\
\text { ська }\end{array}$ & $\begin{array}{l}\text { дебі- } \\
\text { тор- } \\
\text { ська }\end{array}$ & $\begin{array}{l}\text { кре- } \\
\text { ди- } \\
\text { тор- } \\
\text { ська }\end{array}$ & $\begin{array}{l}\text { Дебі- } \\
\text { бітор } \\
\text { тор- } \\
\text { ська }\end{array}$ & $\begin{array}{l}\text { кре- } \\
\text { ди- } \\
\text { тор- } \\
\text { ська }\end{array}$ & $\begin{array}{l}\text { дебі- } \\
\text { тор- } \\
\text { ська }\end{array}$ & $\begin{array}{l}\text { кре- } \\
\text { ди- } \\
\text { тор- } \\
\text { ська }\end{array}$ & $\begin{array}{l}\text { дебі- } \\
\text { тор- } \\
\text { ська }\end{array}$ & $\begin{array}{l}\text { кре- } \\
\text { ди- } \\
\text { тор- } \\
\text { ська }\end{array}$ & $\begin{array}{l}\text { дебі- } \\
\text { тор- } \\
\text { ська. }\end{array}$ & $\begin{array}{l}\text { кре- } \\
\text { ди- } \\
\text { тор- } \\
\text { ська }\end{array}$ \\
\hline $\begin{array}{l}\text { Заборгованість за } \\
\text { товари, роботи, } \\
\text { послуги }\end{array}$ & 16021 & 41312 & - & 25291 & 17836 & 31144 & - & 13308 & 52694 & 39324 & 13370 & - \\
\hline $\begin{array}{l}\text { Заборгованість за } \\
\text { розрахунками } 3 \\
\text { бюджетом }\end{array}$ & 28472 & 390 & 28082 & - & 5739 & 620 & 5119 & - & 81953 & 3623 & 78330 & - \\
\hline $\begin{array}{l}\text { Інша поточна } \\
\text { заборгованість }\end{array}$ & 266 & 280634 & - & 280368 & 161258 & 270027 & - & 108769 & 33648 & 591063 & - & 557415 \\
\hline Разом & 44759 & 322336 & - & 277577 & 184833 & 301791 & - & 116958 & 168295 & 634010 & - & 465715 \\
\hline
\end{tabular}

* розраховано авторами за даними фінансової звітності підприємства

Таблиця 2

Дебіторська і кредиторська заборгованість ПАТ «Одеський олійножировий комбінат», тис. грн.*

\begin{tabular}{|c|c|c|c|c|c|c|c|c|c|c|c|c|}
\hline \multirow{3}{*}{ Показники } & \multicolumn{4}{|c|}{2013 рік } & \multicolumn{4}{|c|}{2014 рік } & \multicolumn{4}{|c|}{2015 рік } \\
\hline & \multicolumn{2}{|c|}{ Заборгованість } & \multicolumn{2}{|c|}{$\begin{array}{c}\text { Перевищення } \\
\text { заборговано- } \\
\text { сті } \\
\end{array}$} & \multicolumn{2}{|c|}{ Заборгованість } & \multicolumn{2}{|c|}{\begin{tabular}{|c|}
$\begin{array}{c}\text { Перевищення } \\
\text { заборговано- } \\
\text { сті }\end{array}$ \\
\end{tabular}} & \multicolumn{2}{|c|}{ Заборгованість } & \multicolumn{2}{|c|}{$\begin{array}{c}\text { Перевищення } \\
\text { заборгованос- } \\
\text { ті } \\
\end{array}$} \\
\hline & $\begin{array}{l}\text { дебі- } \\
\text { тор- } \\
\text { ська }\end{array}$ & $\begin{array}{l}\text { кре- } \\
\text { ди- } \\
\text { тор- } \\
\text { ська }\end{array}$ & $\begin{array}{l}\text { дебі- } \\
\text { тор- } \\
\text { ська }\end{array}$ & $\begin{array}{l}\text { кре- } \\
\text { ди- } \\
\text { тор- } \\
\text { ська }\end{array}$ & $\begin{array}{l}\text { Дебі- } \\
\text { бітор } \\
\text { тор- } \\
\text { ська }\end{array}$ & $\begin{array}{l}\text { кре- } \\
\text { ди- } \\
\text { тор- } \\
\text { ська }\end{array}$ & $\begin{array}{l}\text { дебі- } \\
\text { тор- } \\
\text { ська }\end{array}$ & $\begin{array}{l}\text { кре- } \\
\text { ди- } \\
\text { тор- } \\
\text { ська }\end{array}$ & $\begin{array}{l}\text { дебі- } \\
\text { тор- } \\
\text { ська }\end{array}$ & $\begin{array}{l}\text { кре- } \\
\text { ди- } \\
\text { тор- } \\
\text { ська }\end{array}$ & $\begin{array}{l}\text { дебі- } \\
\text { тор- } \\
\text { ська. }\end{array}$ & $\begin{array}{l}\text { кре- } \\
\text { ди- } \\
\text { тор- } \\
\text { ська }\end{array}$ \\
\hline $\begin{array}{l}\text { Заборгованість за } \\
\text { товари, роботи, } \\
\text { послуги }\end{array}$ & 1693 & 28244 & - & 26551 & 10240 & 47533 & - & 37293 & 30903 & 76297 & - & 45394 \\
\hline $\begin{array}{l}\text { Заборгованість за } \\
\text { розрахунками } 3 \\
\text { бюджетом }\end{array}$ & 1 & 94 & - & 93 & 95 & 95 & - & - & 123 & 19 & 104 & - \\
\hline $\begin{array}{l}\text { Інша поточна } \\
\text { заборгованість }\end{array}$ & 0 & 109156 & - & 109156 & 31 & 66173 & - & 66142 & 369 & 110237 & - & 109868 \\
\hline Разом & 1694 & 137494 & - & 135800 & 10366 & 113801 & - & 103435 & 31395 & 186553 & - & 155158 \\
\hline
\end{tabular}

* розраховано авторами за даними фінансової звітності підприємства

Проаналізувавши кредиторську та дебіторську заборгованості ПАТ «Одеський олійножировий комбінат» за 2013, 2014 та 2015 роки, можна зробити висновок, що за всі три роки заборгованість за товарами, роботами та послугами перевищення йде на кредиторську заборгованість. За 2013 рік становить 26551 тис.грн, 2014 рік - 37293 тис.грн., 2015 рік 45394 тис.грн. В заборгованості за розрахунками 3 бюджетом у 2013 році переважає кредиторська заборгованість на 93 тис.грн., у 2014 році дебіторська заборгованість на рівні кредиторської та складає 95 тис.грн., у 2015 році переважає дебіторська заборго- ваність на 104 тис.грн. У іншій поточній заборгованості переважає кредиторська заборгованість за всі три роки: у 2013 році на 109156 тис.грн., у 2014 році на 66142 тис.грн., у 2015 році на 109868 тис.грн.

Порівняльний аналіз дебіторської та кредиторської заборгованостей у ПАТ «Одеський олійножировий комбінат» за 2013, 2014, 2015 роки показав про загальне перевищення кредиторської заборгованості над дебіторською: у 2013 році на 135800 тис.грн., у 2014 році на 103435 тис.грн., у 2015 році на 155158 тис.грн. 
Порівняльна оцінка дебіторської та кредиторьвий комбінат» представлена в табл. 3. ської заборгованості ПАТ «Іллічівський олійножиро-

Таблиця 3

Дебіторська і кредиторська заборгованість ПАТ «Іллічівський олійножировий комбінат», тис. грн.*

\begin{tabular}{|c|c|c|c|c|c|c|c|c|c|c|c|c|}
\hline \multirow{3}{*}{ Показники } & \multicolumn{4}{|c|}{2013 рік } & \multicolumn{4}{|c|}{2014 рік } & \multicolumn{4}{|c|}{2015 рік } \\
\hline & \multicolumn{2}{|c|}{ Заборгованість } & \multicolumn{2}{|c|}{$\begin{array}{c}\text { Перевищення } \\
\text { заборговано- } \\
\text { сті }\end{array}$} & \multicolumn{2}{|c|}{ Заборгованість } & \multicolumn{2}{|c|}{\begin{tabular}{|c|} 
Перевищення \\
заборговано- \\
сті \\
\end{tabular}} & \multicolumn{2}{|c|}{ Заборгованість } & \multicolumn{2}{|c|}{\begin{tabular}{|c} 
Перевищення \\
заборгованос- \\
ті \\
\end{tabular}} \\
\hline & $\begin{array}{l}\text { дебі- } \\
\text { тор- } \\
\text { ська }\end{array}$ & $\begin{array}{l}\text { кре- } \\
\text { ди- } \\
\text { тор- } \\
\text { ська }\end{array}$ & $\begin{array}{l}\text { дебі- } \\
\text { тор- } \\
\text { ська }\end{array}$ & $\begin{array}{l}\text { кре- } \\
\text { ди- } \\
\text { тор- } \\
\text { ська } \\
\end{array}$ & $\begin{array}{c}\text { Дебі- } \\
\text { бітор } \\
\text { тор- } \\
\text { ська } \\
\end{array}$ & $\begin{array}{l}\text { кре- } \\
\text { ди- } \\
\text { тор- } \\
\text { ська }\end{array}$ & $\begin{array}{l}\text { дебі- } \\
\text { тор- } \\
\text { ська }\end{array}$ & $\begin{array}{l}\text { кре- } \\
\text { ди- } \\
\text { тор- } \\
\text { ська } \\
\end{array}$ & $\begin{array}{l}\text { дебі- } \\
\text { тор- } \\
\text { ська }\end{array}$ & $\begin{array}{l}\text { кре- } \\
\text { ди- } \\
\text { тор- } \\
\text { ська } \\
\end{array}$ & $\begin{array}{l}\text { дебі- } \\
\text { тор- } \\
\text { ська. }\end{array}$ & $\begin{array}{l}\text { кре- } \\
\text { ди- } \\
\text { тор- } \\
\text { ська } \\
\end{array}$ \\
\hline $\begin{array}{l}\text { Заборгованість за } \\
\text { товари, роботи, } \\
\text { послуги }\end{array}$ & 31803 & 2486 & 29317 & - & 46399 & 680 & 45719 & - & 9453 & 1041 & 8412 & - \\
\hline $\begin{array}{l}\text { Заборгованість за } \\
\text { розрахунками } 3 \\
\text { бюджетом }\end{array}$ & 30835 & 110 & 30725 & - & 17863 & 35 & 17828 & - & 342 & 342 & - & - \\
\hline $\begin{array}{l}\text { Інша поточна } \\
\text { заборгованість }\end{array}$ & 38870 & 125298 & - & 86428 & 28755 & 116739 & - & 87984 & 1908 & 592562 & - & 590654 \\
\hline Разом & 101508 & 127894 & - & 26386 & 93017 & 117454 & - & 24437 & 11703 & 593945 & - & 582242 \\
\hline
\end{tabular}

* розраховано авторами за даними фінансової звітності підприємства

Проаналізувавши кредиторську та дебіторську заборгованості ПАТ «Іллічівський олійножировий комбінат» за 2013, 2014 та 2015 роки, можна зробити висновок, що за всі три роки заборгованість за товарами, роботами та послугами перевищення йде на дебіторську заборгованість. У 2013 році переважає на 29317 тис.грн, у 2014 році на 45719 тис.грн., у 2015 році на 8412 тис.грн. В заборгованості за розрахунками 3 бюджетом у 2013 році переважає дебіторська заборгованість на 30725 тис.грн., у 2014 році також переважає дебіторська заборгованість, що становить 17828 тис.грн., у 2015 році дебіторська заборгованість на рівні кредиторської на рівні кредиторської та складає 342 тис.грн. У іншій поточній заборгованості переважає кредиторська заборгованість за всі три роки: у 2013 році на 86428 тис.грн., у 2014 році на 87984 тис.грн., у 2015 році на 590654 тис.грн.

Порівняльний аналіз дебіторської та кредиторської заборгованостей у ПАТ «Іллічівський олійножировий комбінат» за 2013, 2014, 2015 роки показав про загальне перевищення кредиторської заборгованості над дебіторською: у 2013 році на 26386 тис.грн., у 2014 році на 24437 тис.грн., у 2015 році на 582242 тис.грн.

Висновки та перспективи подалыших досліджень. Для найбільш об'єктивної оцінки платоспроможності підприємства необхідно використовувати відомості про дебіторську і кредиторську заборгованість. Дебіторська і кредиторська заборгованості виникають внаслідок використання безготівкових розрахунків підприємства 3 покупцями, підрядчиками, фінансовими органами, робітниками, службовцями, органами соціального страхування, депонентами, підзвітними особами, тощо. При діючих формах розра- хунків момент відвантаження готової продукції, виконання робіт, послуг, одержання товарноматеріальних цінностей, нарахування зарплати і платежів не співпадає з моментом їх оплати. Ці умови призводять до виникнення дебіторської та кредиторської заборгованості. Значні розміри дебіторської та кредиторської заборгованості призводять до самовільного перерозподілу обігових коштів між підприємствами.

Отже, порівнявши дебіторську і кредиторську заборгованість на підприємствах: ПАТ «Вінницький олійножировий комбінат», ПАТ «Одеський олійножировий комбінат», ПАТ «Іллічівський олійножировий комбінат», можна зробити висновок, що на кожному підприємстві переважає кредиторська заборгованість. Переважання кредиторської заборгованості над дебіторською свідчить про те, що підприємства в майбутньому не зможуть погасити свою кредиторську заборгованість за рахунок дебіторської.

В такому випадку, підприємствам слід вжити заходів щодо управління дебіторською та кредиторською заборгованістю, яке передбачає:

- обгрунтування можливості виникнення дебіторської та кредиторської заборгованості;

- контроль розрахунків 3 дебіторами (кредиторами) за відстрочену або прострочену заборгованість та вивчення причин недотримання договірної дисципліни;

- аналіз і ранжування покупців (постачальників) у залежності від обсягів закупівель, історії кредитних відносин і запропонованих умов оплати;

- своєчасне визначення прийомів прискорення боргів і зменшення безнадійних боргів;

- прогноз надходжень грошових коштів від 
дебіторів на основі коефіцієнтів інкасації;

- визначення політики надання кредиту та інкасації для різних груп покупців (постачальниками) i видів продукції;
- забезпечення умов продажу, що гарантують надходження грошових коштів.

\title{
Література
}

1. Барановська А. С. Оцінка ефективності дебіторської та кредиторської заборгованості / А. С. Барановська // Фінанси і кредит. - 2010. - №1. - С. 57-62

2. Білик М. Д. Управління дебіторською заборгованістю підприємств / М. Д. Білик // Фінанси України. 2003. - № 12. - С. 24-36

3. Блонська В. І. Вдосконалення управління дебіторською заборгованістю торговельних підприємств в умовах дефіциту оборотних коштів / В. І. Блонська, Н. Б. Толопка // Наука й економіка. - 2009. - №4 (16), Т. 2. - C. $65-74$

4. Горбачова О. М. Облік і аналіз дебіторської заборгованості: проблеми та шляхи їх вирішення / О. М. Горбачова, Л. В. Лахай // Торгівля і ринок. - 2010. - № 30, Т. 2. - С. 392-399

5. Дубровська Е. Управление дебиторской задолженностью / Е. Дубровська, В. Смачило // Финансовый директор. - 2007. - № 5. - С. 47-53

6. Джалал Т. К. Аналіз дебіторської і кредиторської заборгованості підприємства / Т. К. Джалал // Економічний аналіз: теорія і практика. - 2006. - № 7. - С.116-123

7. Ізмайлова Н. В. Стан та тенденції дебіторської та кредиторської заборгованості: макроекономічний аспект / Н. В. Ізмайлова // Вісник економіки, транспорту і промисловості. - 2010. - №29. - С. 124-126

8.Кляшко О. М. Аналіз дебіторської заборгованості в системі управління підприємством : автореф. дис. на здобуття наук. ступеня канд. ек. наук : спец. 08.00.09 «Бухгалтерський облік, аналіз та аудит (за видами економічної діяльності)» / Кляшко О. М. - К., 2011. - 21 с.

9.Крейнина М. Н. Управление движением дебиторской и кредиторской задолженности предприятия / М. Н. Крейнина // Финансовый менеджмент. - 2009. - № 3. - С. 34-39

10. Лищенко О. Г. Аналіз дебіторської заборгованості в системі управління підприємством / О. Г. Лишенко // Запоріжжя: Гуманіст. - 2009. - №1. - С. 114-117

11. Лищенко О. Г. Управління дебіторською заборгованістю як фактором фінансової стійкості підприємства / О. Г. Лищенко, І. С. Середа // Держава та регіони. Серія: Економіка і підприємництво. - 2010. - №3. - С. 84-89

12. Момот Т. Управление дебиторской задолженностью предприятия / Т. Момот // Бизнес-информ. - 2003. - № 11-12. - С. 97-99.

13. Ніколаєнко О. Деякі аспекти аналізу дебіторської заборгованості суб’єктів господарювання / О. Ніколаєнко // Підприємство, господарство і право. - 2004. - № 7. - С. 141-145 $480 \mathrm{c}$.

14. Савчук В.П. Управление финансами предприятия / В. П. Савчук. - М. : Бином, лаб. знаний, 2003. -

15. Боді Зві. Фінанси: навч. посіб./ Зві Боді, Роберт Мертон; пер. з анг. - М. : Видавн. дім «Вільямс», 2000. -592 c.

Стаття надійшла 10.04.2017 Стаття прийнята до друку 24.04.2017 Доступно в мережі Internet 30.06.2017

\author{
Евтушевская О.А. \\ кандидат экономических наук, доцент \\ E-mail: olga163alex@gmail.com \\ Кустурова С.П. \\ магистрант \\ кафедра учета и аудита \\ Одесская национальная академия пищевых технологий \\ ул. Канатная, 112, г. Одесса, Украина, 65039 \\ E-mail:kusturova.sveta@yandex.ru
}

\section{СРАВНИТЕЛЬНАЯ ОЦЕНКА ДЕБИТОРСКОЙ И КРЕДИТОРСКОЙ ЗАДОЛЖЕННОСТИ ПРЕДПРИЯТИЙ}

В статье исследована сущность, цели и порядок формирования анализа дебиторской и кредиторской задолженностей. Установлено, что очень большое значение для предприятий имеют анализ 
и управление дебиторской и кредиторской задолженностью, функционирующих в условиях рынка. Достаточно эффрективное и умелое управление этой частью текущих активов является неотъемлемым условием поддержания необходимого уровня ликвидности и платежеспособности. Установлено, что дебиторская и кредиторская задолженности возникают вследствие использования безналичных расчетов предприятия с покупателями, подрядчиками, фринансовыми органами, рабочими, служащими, органами социального страхования, депонентами, подотчетными лицами.

Определено, что главной задачей управления движением дебиторской задолженности является установление с покупателями таких договорных отношений, обеспечивающих своевременное и достаточное поступление средств для осуществления платежей кредиторам. Установление таких договорных взаимоотношений с поставщиками, которые ставят сроки и размеры платежей предприятия последним в зависимость от поступления денежных средств от покупателей является главной задачей управления движением кредиторской задолженности.

Осуществлен сравнительный анализ дебиторской и кредиторской задолженностей на предприятиях. Проведенные исследования показали, что на протяжении последних лет, на каждом предприятии преобладает кредиторская задолженность, и свидетельствует о том, что предприятия в будущем не смогут погасить свою кредиторскую задолженность за счёт дебиторской. Предложено принятие мер по управлению дебиторской и кредиторской задолженностью.

Ключевые слова: дебиторская задолженность, кредиторская задолженность, сравнение, анализ, оценка.

\author{
Yevtushevska 0. \\ $\mathrm{PhD}$, Associate Professor \\ E-mail: olga163alex@gmail.com \\ Kusturova S. \\ Undergraduate \\ Department of Accounting and Auditing \\ Odessa National Academy of Food Technologies \\ Kanatna Str., 112, Odessa, Ukraine, 65039 \\ E-mail:kusturova.sveta@yandex.ru
}

\title{
COMPARISON OF RECEIVABLES AND PAYABLES
}

The essence, goals and the order of formation of the analysis of accounts receivable and accounts payable are investigated in the article. It is established that the analysis and management of accounts receivable and accounts payable, functioning in the conditions of the market, are very important for enterprises. Sufficiently effective and skilful management by this part of current assets is an indispensable condition for maintaining the required level of liquidity and solvency. It is established that accounts receivable and payable arise due to the use of non-cash settlements of the enterprise with buyers, contractors, financial authorities, workers, employees, social insurance bodies, depositors, accountable persons.

It is determined that the main task of managing the movement of receivables is to establish with the buyers such contractual relations that would ensure timely and sufficient receipt of funds for making payments to creditors. Establishment of such contractual relationships with suppliers that set the terms and amounts of the enterprise payments to the last place depending on the receipt of funds from customers is the main task of managing the movement of accounts payable.

A comparative analysis of accounts receivable and payable at enterprises was carried out. The conducted research showed that over the last years, at each enterprise the accounts payable predominated, and it shows that the enterprises in the future will not be able to pay their accounts payable at the expense of the accounts receivable. Taking measures concerning management of receivables and payables has been offered.

Keywords: accounts receivable, accounts payable, comparison, analysis, evaluation

\section{References}

1. Baranovska , A. S. (2010). Otsinka efektyvnosti debitorskoi ta kredytorskoi zaborhovanosti. Finansy i kredyt, 1, 57-62.

2. Bilyk , M. D. (2003). Upravlinnia debitorskoiu zaborhovanistiu pidpryiemstv. Finansy Ukrainy, 12, 24-36. 
3. Blonska , V. I. (2009). Vdoskonalennia upravlinnia debitorskoiu zaborhovanistiu torhovelnykh pidpryiemstv v umovakh defitsytu oborotnykh koshtiv. Nauka i ekonomika, 4(16), 65-74.

4. Horbachova , O. M. (2010). Oblik i analiz debitorskoi zaborhovanosti: problemy ta shliakhy yikh vyrishennia. Torhivlia i rynok, 30(2), 392-399.

5. Dubrovska, E., \& Smachylo, V. (2007). Upravlenye debytorskoi zadolzhennostiu. Fynansovbi dyrektor, 5, 47-53.

6. Dzhalal , T. K. (2006). Analiz debitorskoi i kredytorskoi zaborhovanosti pidpryiemstva. Ekonomichnyi analiz: teoriia i praktyka, 7, 116-123.

7. Izmailova , N. V. (2010). Stan ta tendentsii debitorskoi ta kredytorskoi zaborhovanosti: makroekonomichnyi aspekt. Visnyk ekonomiky, transportu i promyslovosti, 29, 124-126.

8. Kliashko , O. M. (2011). Analiz debitorskoi zaborhovanosti v systemi upravlinnia pidpryiemstvom . K.

9. Kreinyna, M. N. (2009). Upravlenye dvyzhenyem debytorskoi y kredytorskoi zadolzhennosty predpryiatyia . Fynansovыi menedzhment, 3, 34-39.

10. Lyshchenko, O. H. (2009). Analiz debitorskoi zaborhovanosti v systemi upravlinnia pidpryiemstvom . Zaporizhzhia: Humanist, 1, 114-117.

11. Lyshchenko, O. H. (2010). Upravlinnia debitorskoiu zaborhovanistiu yak faktorom finansovoi stiikosti pidpryiemstva . Derzhava ta rehiony. Seriia: Ekonomika i pidpryiemnytstvo, 3, 84-89.

12. Momot , T. (2003). Upravlenye debytorskoi zadolzhennostiu predpryiatyia. Byznes-ynform, 11-12, 97-99.

13. Nikolaienko , O. (2004). Deiaki aspekty analizu debitorskoi zaborhovanosti sub'iektiv hospodariuvannia . Pidpryiemstvo, hospodarstvo i pravo, 7, 141-145.

14. Savchuk, V. P. (2003). Upravlenye fynansamy predpryiatyia . Bynom, lab. znanyi.

15. Bodi Zvi. Finansy: navch. posib. (2000). M.: Vydavn. dim «Viliams». 